\title{
Key Success Factors Of Line Of Balance (LOB) And M-PERT Integration On The Development Of Wastewater Treatment Plant
}

\author{
Albert Eddy Husin, Hari Meidiyanto, Tri Laksana Setyawan, Bernadette Detty \\ Kussumardianadewi, Michael Kelvin Eddy Husin
}

\begin{abstract}
The construction of a wastewater treatment plant in Indonesia to overcome domestic wastewater discharges has experienced many delays so that people are threatened not to enjoy development facilities that can protect them from the dangers of environmental pollution. The purpose of this paper is to analyze the application of the LOB and M-PERT scheduling methods by identifying the factors that influence the application of the two scheduling methods and how the results of the analysis are implemented $A$ total of 40 questionnaires were distributed to consultant planners and supervisors of wastewater treatment plant and with the RII (Relative Importance Index) statistical analysis method it was found that the most influential factors were analysis of M-PERT activities in the form of combining activities in one group and on alternative pathways, and calculating reset PERT. Analysis of $\mathrm{LOB}$ implementation is in the form of optimizing project time, relationship logic activities, analysis of buffer time determination, and duration of work units. Schedule in the form of land ownership, inability to acquire required permission, and the influence of local custom and religious events. Based on these findings, the speakers recommend the following: 1) The planning consultant can socialize the application of the LOB and M-PERT methods to all stakeholders involved starting from contractors, field supervisors, and the local City Government; 2) Encouraging local City Government to be able to increase the number of wastewater treatment plant facilities built; 3) Increase the number of city residents who are protected from the dangers of environmental pollution with the wider scope of services provided.

Index Terms: wastewater treatment plant, LOB, M-PERT, RII.
\end{abstract}

\section{INTRODUCTION}

Along with the increase in population, the threat of decreasing water quality due to wastewater discharge remains a global problem. Improvement of wastewater access services in developing countries continues with efforts to treat wastewater.

Revised Manuscript Received on October 30, 2019.

* Correspondence Author

Albert Eddy Husin*, Master Program of Civil Engineering, Mercu Buana University, Jakarta, Indonesia,

Hari Meidiyanto, Master Program of Civil Engineering, Mercu Buana University, Jakarta, Indonesia.

Tri Laksana Setyawan, Master Program of Civil Engineering, Mercu Buana University, Jakarta, Indonesia.

Bernadette Detty Kussumardianadewi, Master Program of Civil Engineering, Mercu Buana University, Jakarta, Indonesia.

Michael Kelvin Eddy Husin, Master Program of Mining Engineering, Institut Teknologi Bandung, Bandung,Indonesia.

(c) The Authors. Published by Blue Eyes Intelligence Engineering and Sciences Publication (BEIESP). This is an open access article under the CC BY-NC-ND license (http://creativecommons.org/licenses/by-nc-nd/4.0/)
Current trends related to urban and industrial wastewater treatment plant problems illustrate that on average in new high-income countries it is able to treat $70 \%$ of wastewater, while middle to upper-income countries (including Indonesia) is around $38 \%$, and middle-income countries to down about $28 \%$, the last low-income country is only $8 \%$ in urban and industrialwastewater [1].One of the factors that cause low urban and industrial wastewater treatment capacity as a whole is a delay in the implementation of the construction of waste water treatment plants, where many factors are influenced by shortages of labor, project location, weather, competency of project implementers, large investment costs treatment plant and others [2],[3].

On average, the construction of waste water treatment plants has a delay of mostly 20\% and can be seen in Figure 1 five World Bank and ADB projects[4],[5]. The average delay in the construction of waste water treatment plants in Indonesia in 2018 is 36\% as $20 \%$ and shown in Figure 1.

To overcome the delay in the construction of a wastewater treatment plant, it is necessary to use the Line of Balance (LOB) scheduling method because the construction of a waste water treatment plant is carried out in many places and repeated with the same building construction design [6]-[9]. While the use of the M-PERT scheduling method is intended to obtain the accuracy of the completion time of construction [10].

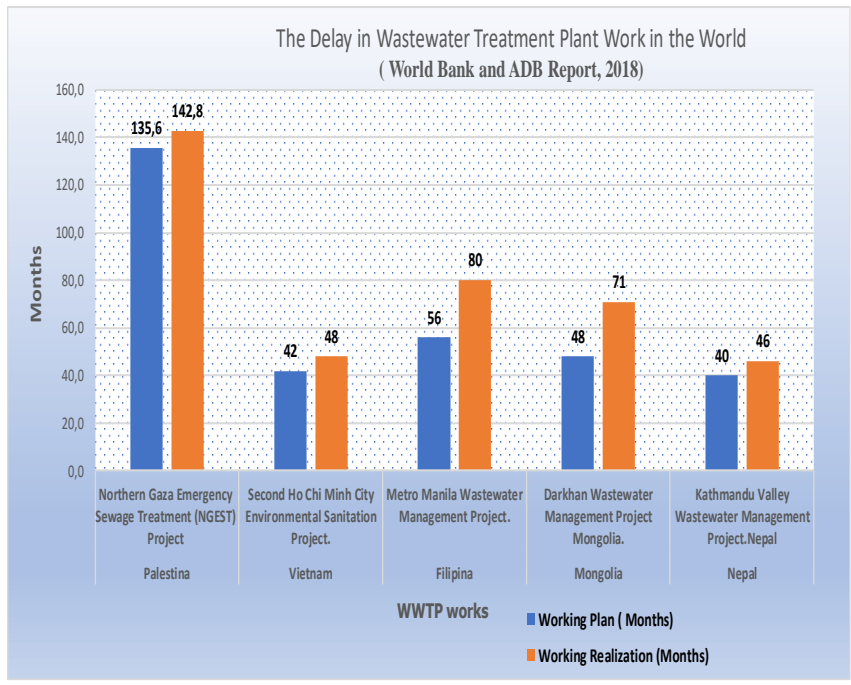

Figure 1. Delay In Wastewater Treatment Plant Work In The World

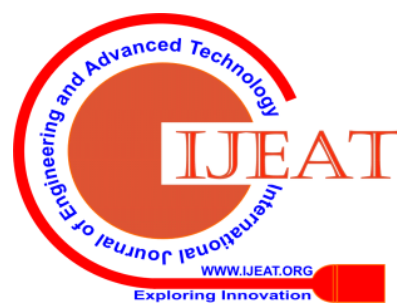




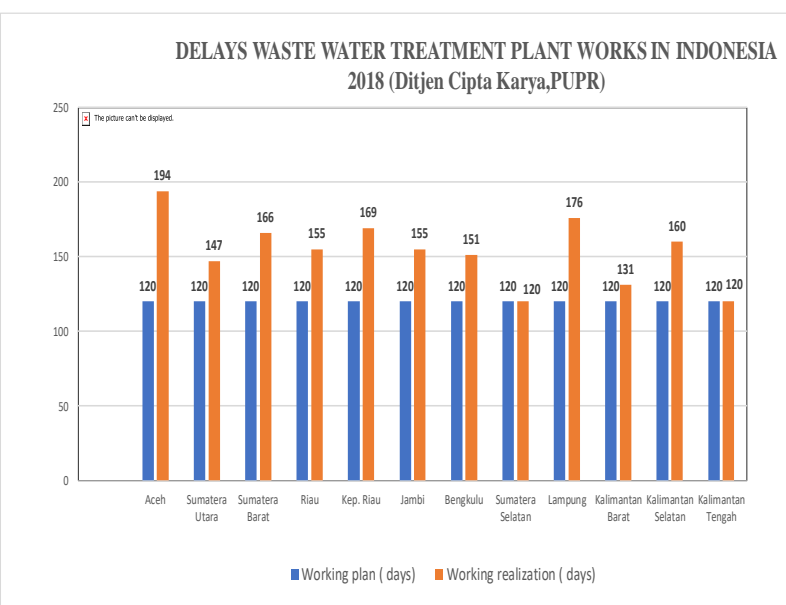

Figure 2.Delay in wastewater treatment plant work in Indonesia

Figures for the Environmental Performance Index (EPI) provide information on environmental management performance ratings in the world which include indicators of air pollution, water, and sanitation which include wastewater, forestry, agriculture, and others and Indonesia's position is still ranked 133 out of 180 countries in the world with EPI 46.92. Switzerland's highest EPI number reaching 87.42 and the lowest in Burundi is 27.43 as shown in figure 1.3, with dark blue having numbers 50 - 100 and light blue at numbers $0-50$ as seen in figure 3 below [11].

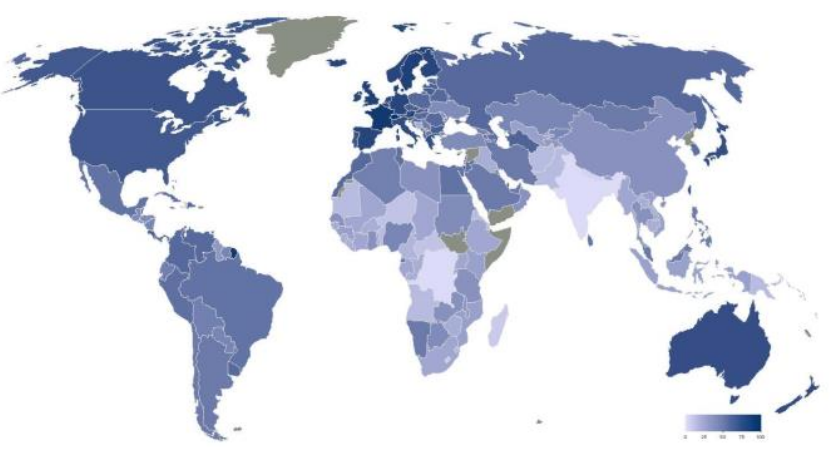

Figure 3.

Environmental Performance Index (EPI) Score In The World

\section{IMPLEMENTATION OF LOB AND M-PERT METHOD INTEGRATION}

The construction of a wastewater treatment plant in cities built in bulk through the 2018 state budget funding has been built by 41 units in 13 provinces of Sumatra and Kalimantan, but it has been slow, even though the planning design is the same, which is not achieved. For this reason, the integration of LOB and M-PERT scheduling methods is carried out in order to help optimize the timing of the construction of a wastewater treatment plant that is carried out repeatedly in several locations and to achieve accurate completion time due to limited financing time from the APBN [12]-[14]. The application of the integration of the LOB and M-PERT scheduling methods will help the City Government in meeting the target number of wastewater treatment plant facilities that must be built within a budget year. And next year the City Government can plan to build more wastewater treatment plant facilities so that the target that all residents can get adequate access to wastewater treatment plant facilities can be met in stages.

\section{RESEARCH METHODOLOGY}

The design of the study begins with the following steps: 1) Work begins with gathering literature studies and identifying problems with delays in waste water treatment plant projects from international journals and national journals; 2) From the literature study and identification of problems, the title of the research can be obtained and continued by conducting a research gap to ensure research gaps are available; 3) Arranging State of the Arts in order to ensure there are no similar studies and avoid plagiarism in this study; 4) Formulate the problem (Research Question) about the application of the Line of Balance (LOB) and M-PERT methods and set research goals (Research Aim) to answer the Research Question and compile the research hypothesis; 5) Compile research methods that include the process of construction work, identification of variables, data collection and compiling testing models and hypotheses; 6) Collect primary and secondary data and qualitative and quantitative data on the construction of waste water treatment plants in 2018; 7) Continued by validating the data process with statistical analysis using the RII (Relative Importance Index) method, where this method has been used throughout the world in research; 10) From all the steps above, conclusions and suggestions can be drawn for the next step of the research. A detailed description of the research design can be seen in figure 4 below [15].

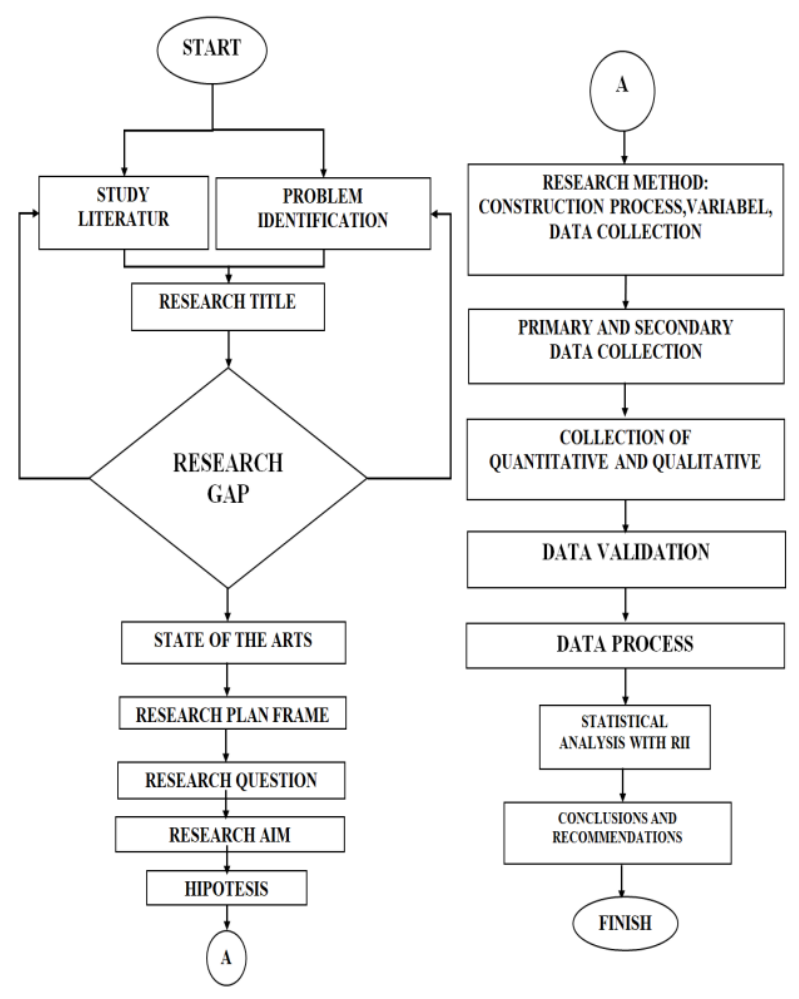

Figure 4. Research Methodology 
This questionnaire survey is used to obtain any factors that influence the application of LOB and M-PERT scheduling methods in the construction of a wastewater treatment plant. 40 Respondents from the site engineer, site manager, and project manager were asked to respond to 44 sub-factors identified using numbers 1 - 5 on a Likert scale, where 1 is not considered influential, 2 is considered as having no effect, 3 is considered as influential enough, 4 is considered as influential and 5 is very influential based on the experience they face every day. The questionnaire before being distributed has been limited to those who understand and understand the LOB and M-PERT methods so that later the respondents will be able to understand in completing the questionnaire.

The results of data collection from all respondents illustrate that the questionnaire data sent by the author of 45 pieces and who returned 40 the number of questionnaires has met the minimum requirements for use in research by following the minimum number of respondents. The details of the return of the questionnaire are as follows:

Tabel 1. Data Collection

\begin{tabular}{|c|c|c|c|}
\hline Questionnaire & Sent & Returned & $\begin{array}{c}\text { Percentage } \\
(\%)\end{array}$ \\
\hline Hardcopy & 45 & 40 & 89 \\
\hline
\end{tabular}

Profile of respondents in the study had sex dominated by men by $70 \%$ and women only $30 \%$ with the number of details of respondents can be seen in the Figure 5 below.

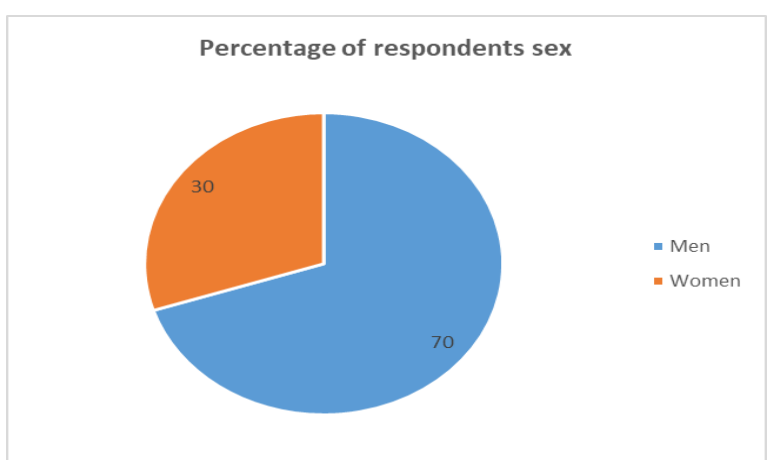

Figure 5. Percentage of respondents sex

Distribution of respondents by age was dominated by age $>$ 51 years and the smallest respondents were $<30$ years old and 31 - 40 years old as shown in the Figure 6 below.

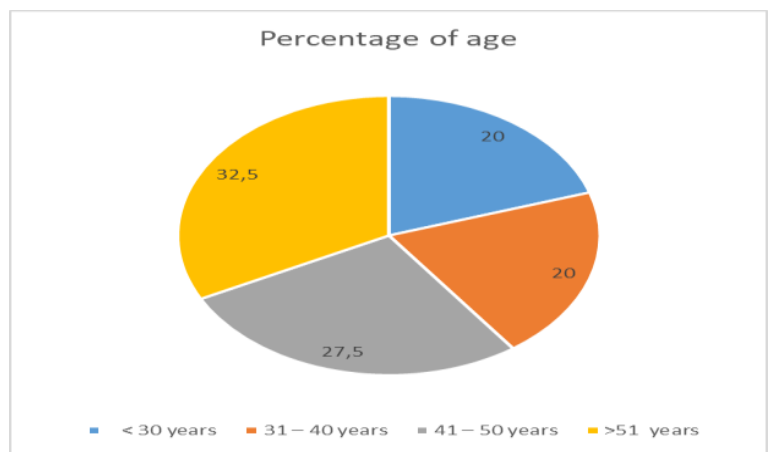

Figure 6. Percentage of age

Whereas the education level of the respondents is dominated by civil engineering and environmental engineering scholars with a bachelor $85 \%$ and the lowest Diploma 3 of $5 \%$ as can be seen in the Figure 7 below.

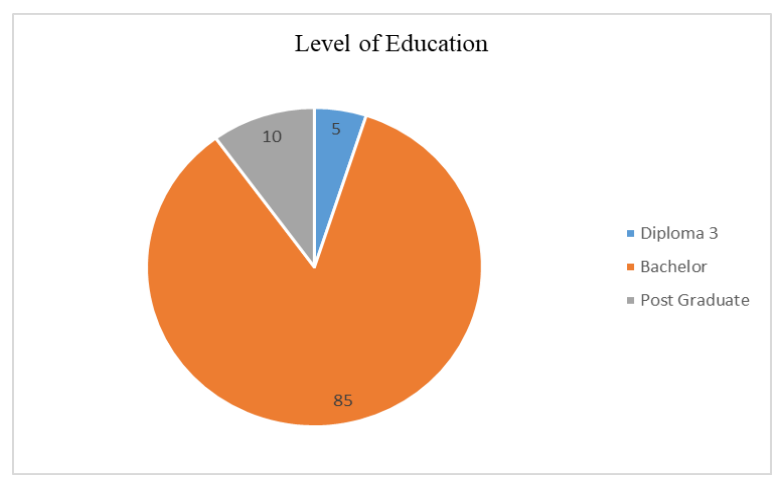

Figure 7. Level Education respondents

Most of the respondents' positions in the research target are Project Managers of $70 \%$ and the smallest as site managers and site engineers of $5 \%$ as can be seen in the Figure 8 below.

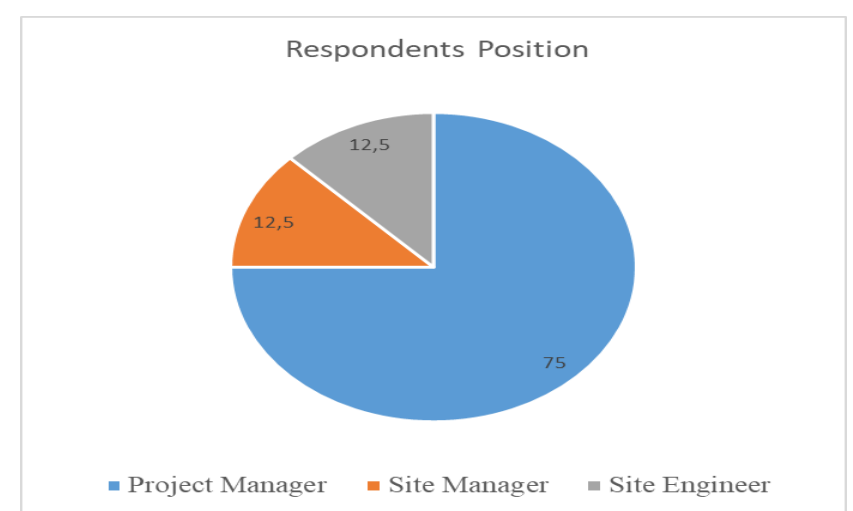

Figure 8. Respondents position

Respondent's work experience is dominated by over 15 years working period of $57.5 \%$, then $20 \%$ of respondents have a working period of 5 - 10 years, 10 years - 15 years work period of $17.5 \%$ and the smallest $5 \%$ with $<5$ years work experience. Respondent's work experience can be seen in the Figure 9 below.

\section{Work Experience of Respondent}

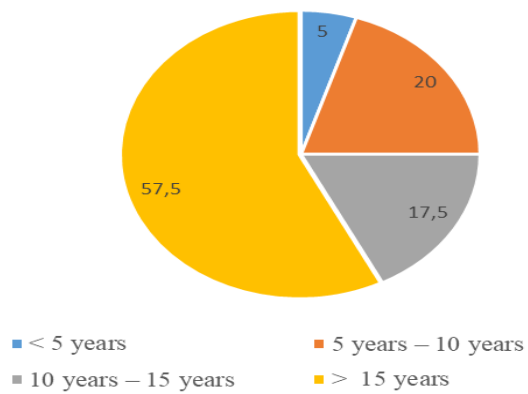

Figure 9. Work experience of the respondent

The type of work carried out by respondents was dominated by wastewater treatment construction work of 55\%, followed by the construction of buildings equipped with STP (Sewage Treatment Plant) of $45 \%$ as can be seen in Figure 10 below. 


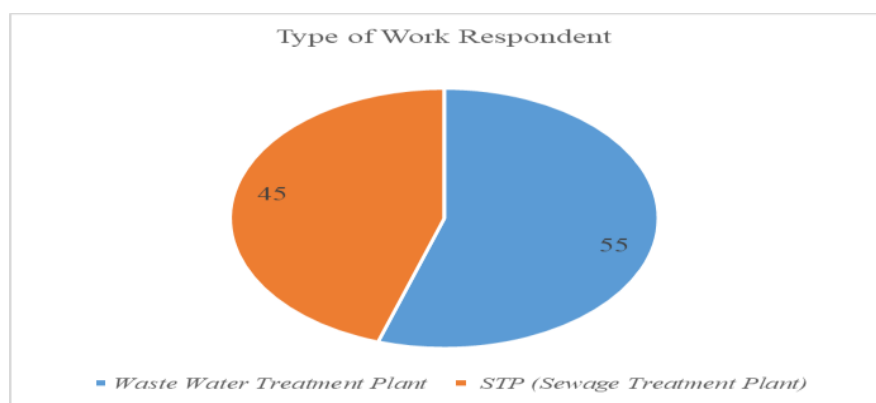

Figure 10. Type Of Work Respondents

44 of these sub-factors come from 9 main factors based on literature studies [4],[15],[10]. The main factor consists of the Line of Balance method in the aspects of scheduling, planning, implementing, and analyzing implementation. The M-PERT method is in the aspect of M-PERT activity analysis and M-PERT planning as well as the construction of a wastewater treatment plant on aspects of preparation for implementation, supervision, and schedule [16],[17]. While the data processing method uses a scheme as shown in the Figure 11 below.

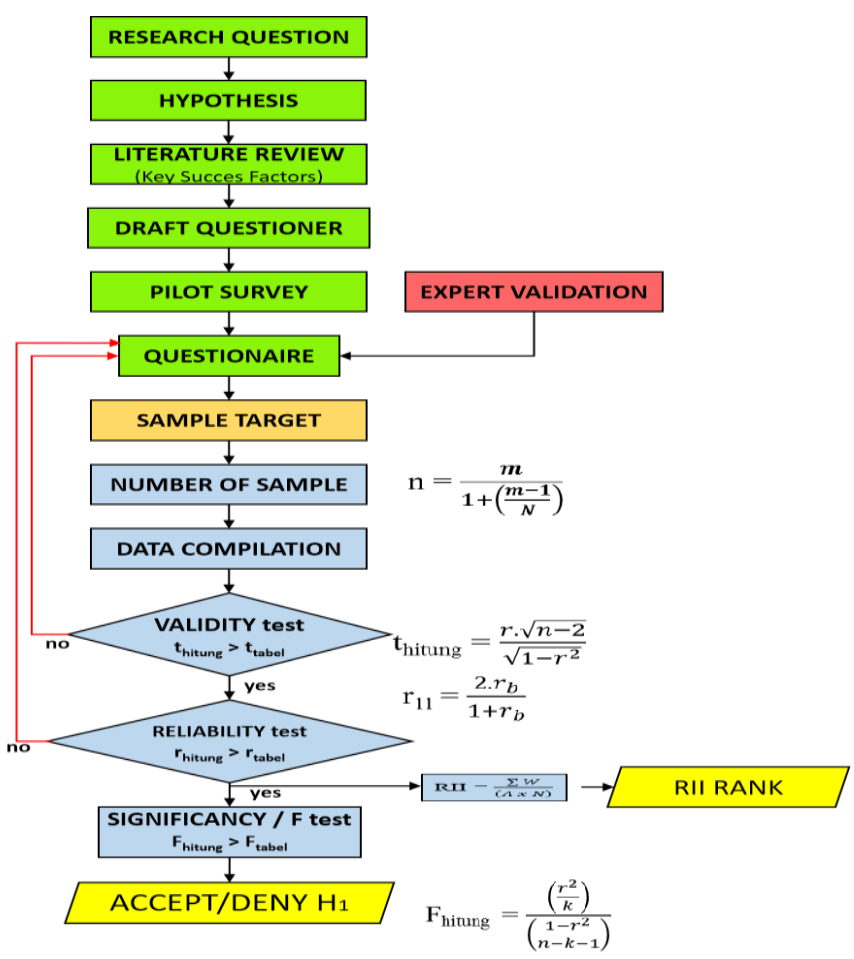

Figure 11. Data Processing Method

The statistical analysis method in this study uses the Relative Importance Index (RII) method based on equation 1 below [18],[19].

$$
\mathrm{RII}=\left(\sum \mathrm{W} / \mathrm{A} \times \mathrm{N}\right)
$$

\section{RESULT AND DISCUSSION}

The results of statistical analysis with the RII method on 10 sub-factors, where the highest score of RII is 0.995 and the lowest is 0.950 can be seen in Table 2 below.

\section{Table 2. The Most Influential Variable}

\begin{tabular}{|c|l|c|}
\hline Rank & \multicolumn{1}{|c|}{ Sub Factor } & RII Score \\
\hline 1 & Combining 1 group activities & 0,995 \\
\hline 2 & Merging of alternative lane activities & 0,990 \\
\hline 3 & Recalculating PERT & 0,985 \\
\hline 4 & Project time Optimization & 0,980 \\
\hline 5 & Relationship logic activities & 0,975 \\
\hline 6 & Analysis of buffer time determination & 0,970 \\
\hline 7 & Duration of work unit & 0,965 \\
\hline 8 & Land ownership & 0,960 \\
\hline 9 & Inability to acquire required permission & 0,955 \\
\hline 10 & Effect of local custom \& religious events & 0,950 \\
\hline
\end{tabular}

Table 2 showed the top 10 most influential sub-factors in applying the LOB and M-PERT scheduling method based on the choice of respondents has a high RII number in the range between 0.950 - 0.995, where the sub-factor of the M-PERT main factor is like combining one group activity, combining activities on alternative paths and recalculating PERT. Sub factors of the LOB method such as s of project time, relationship logic activities, and analysis of buffer time determination and duration of work units. Whereas the land ownership sub-factor, inability to acquire required permission and the influence of local custom and religious events is the main factor of the schedule of the wastewater treatment plant work.

\section{CONCLUSION}

1. There is a significant influence of LOB and M-PERT integration utilization to the final duration of the wastewater treatment plant construction project.

2. The 10 most influential factors of the utilization of the line of balance and M-PERT scheduling method integration consists of combining 1 group activities, merging of alternative lane activities, recalculating PERT, project time optimization, relationship logic activities, analysis of buffer time determination, duration of work unit, land ownership, the inability to acquire required permission, and the effect of local custom \& religious events.

3. The resulting 10 most influential factors could be used by planning consultant on wastewater treatment plant construction project activity scheduling to reach higher efficiency and effectivity.

\section{REFERENCES}

1. Water U.(2017), "World Water Development Report " www.unwater.org.

2. Umar T.(2018)," Causes of delay in construction projects in Oman" Middle East J Manag.5(2):121. doi:10.1504/mejm.2018.091132

3. Ahmed T.(2015)," Delay Construction Project" www.researchgate.net/publication/306032747

Note :

RII: Relative Importance Index

$\mathrm{W}$ : Weight ( range $1-5$ )

A: Highest weight, 5

$\mathrm{N}$ : Total respondent 
4. Tikote RH, Magdum MM, Khandare MA.(2017), " Delay Analysis in Industrial Projects" By. Int Res J Eng Technol. 2017;4(6). https://irjet.net/archives/V4/i6/IRJET-V4I6377.pdf.

5. Feyzbakhsh S, Telvari A, Reza A.(2017), "Investigating the Causes of Delay in Construction of Urban Water Supply and Wastewater Project in Water and WasteWater Project in Tehran" www.CivileJournal.org Vol.3,No.12.

6. Duffy GA.(2003)," LINEAR SCHEDULING OF PIPELINE CONSTRUCTION PROJECTS. Faculty of Graduate College of Oklahoma State University.

7. Jiang A, Cheng B, Flood I, Issa R.(2006)," Modified Linear Scheduling in Scheduling Multiple Utility Line Construction Project. http://irandanesh.febpco.com/FileEssay/civil-86-1-3-b-sy(31).pdf.

8. Su Y, Lucko G.(2015)," Comparison and Renaissance of Classic Line-of-balance and Linear Schedule Concepts for Construction Industry. Procedia Eng. 2015;123(November 2015):546-556. doi:10.1016/j.proeng.2015.10.107

9. Seppänen O, Aalto E.(2005),"A Case Study of Line-of-balance Based Schedule Planning and Control System. Annu Conf Int Gr LEAN Constr 13. 2005;(January 2005):271-279. http://iglc.net/Papers/Details/373.

10. Ballesteros-Pérez P.(2017),"M-PERT: Manual Project-Duration Estimation Technique for Teaching Scheduling Basics. J Constr Eng Manag. doi:10.1061/(asce)co.1943-7862.0001358

11. Yale Center.(2018),"Environment Performance Index" Yale University and Columbia University in collaboration with the World Economic Forum

12. ElZein Z, Abdou A, ElGawad IA.(2016)," Constructed Wetlands as Sustainable Wastewater Treatment Method in Communities"Procedia Environ Sci. 2016;34:605-617. doi:10.1016/j.proenv.2016.04.053

13. Kumar Pitta and John Ratnakanth Babu.(2010)," Performance Evaluation of WasteWater Treatment Plant" doi:10.1115/wtc2005-63608

14. Arnold RG, Woods GJ, Kang D, Lansey KE, Du F.(2012)," Life Cycle Analysis for Water and Wastewater Pipe Materials" J Environ Eng. 2012;139(5):703-711. doi:10.1061/(asce)ee.1943-7870.0000638

15. Vosoughi P, Telvari A, Lork A.(2017)," Identification and Evaluation of Factors Effecting on Delay in Water and Sewage Project in Tehran" International Journal for Research in Applied Science \& Engineering Technology (IJRASET)

16. Husin, A.E., Sulistyaningtyas, C.B.(2018)," Project by M-PERT utilization Time performance improvement of hospital building structure construction project by M-PERT utilization" IJSRET,ISSN 2278 - 0882 Volume 7, Issue 10, October 2018

17. Husin, A.E.,Kussumardianadewi, B.D.,Susandi.(2019)," TIME PERFORMANCE UPGRADE ON TOLL ROAD CONSTRUCTION PROJECT BY M-PERT"www.ijcrls.com 2019;08(01):3035-3042.

18. Enshassi A, Mohamed S, Abushaban S.(2009)," Factors Affecting the Performance of Construction Projects in the Gaza Strip" J Civ Eng Manag. 2009;15(3):269-280 doi:10.3846/1392-3730.2009.15.269-280

19. Aziz RF.(2013),"Ranking of delay factors in construction projects after Egyptian revolution" Alexandria Eng J. 2013;52(3):387-406. doi:10.1016/j.aej.2013.03.002 